\title{
THE ABILITY OF STUDENTS OF LAW FACULTY IN ACADEMIC YEAR 2018/2019, ISLAMIC UNIVERSITY OF INDRAGIRI TO IDENTIFY PREPOSITION OF TIME IN A SENTENCE
}

\author{
Agus Mustajib \\ FKIP (Faculty of Teacher Training and Education) \\ Islamic University of Indragiri \\ E-mail:najibsaputra273@gmail.com
}

\begin{abstract}
Languages are not just sets of symbols. They also often conform to a rough grammar, or system of rules, used to manipulate the symbols. The grammar of a language is a complex and highly structured affair because it operates in terms of concepts and categories which have to be defined in the same way. So we need a grammar in using English and an understanding of the grammar also influences our ability in English. The students of Law Faculty 2018/2019, Islamic University of Indragiri are the students who are studying English in the first and second semester. So, the researcher is eager to know their ability to identify preposition of time in the sentences. The study focuses on the students' ability in identifying preposition of time in a sentence especially "on, in, and at". The number of the first semester of Law Faculty consists of three classes and the total of the students are 118 students. The populations are more than 100 students, so the researcher used a random sampling technique. The researcher can take the sample about $15 \%$ to $25 \%$ or more like the sample and the researcher take half of $100 \%$ is $50 \%$. So, the samples of this research are 69 students. The researcher used a quantitative method to get the data needed. The research instrument in this research is to test and fill in the blank forms. The researcher used a sentence without preposition as the instrument of this research, because the students learned preposition through sentences. Based on the result of the test, the mean score of preposition was 63.98. It was categorized at a good level, which included in the interval 61-80. Where there are 6 students get in a very good score, 26 students get in a good score, 36 students get in enough score, 1 student get the poor score and there is no get in a very poor score. In conclusion, the students of Law Faculty 2018/2019 in identify preposition categorized nice and understand in the preposition.
\end{abstract}

Keywords: Ability, preposition of time, sentence 


\begin{abstract}
Abstrak
Bahasa bukan hanya ketetapan simbol-simbol. Akan tetapi bahasa juga merupakan penyusuaian dengan tata bahasa, atau sistem aturan yang digunakan untuk mengunakan simbol tersebut. Tata bahasa memiliki masalah yang kompleks dan sangat terstruktur karena ia berperan dalam hal konsep dan kategori yang harus didefinisikan dengan cara yang sama. Jadi kita perlu tatabahasa dalam memahami dan menggunakan bahasa Inggris mempengaruhi kemampuan kita dalam bahasa Inggris. Para mahasiswa fakultas hukum 2018/2019, Universitas Islam Indragiri adalah mahasiswa yang belajar bahasa Inggris di semester pertama dan kedua. Jadi, saya ingin tahu kemampuan mereka untuk mengidentifikasi prepotition of time dalam kalimat. Penelitian ini fokus pada kemampuan siswa dalam mengidentifikasi prepotition of time dalam kalimat terutama "on, in, dan at". Jumlah semester pertama fakultas hukum terdiri dari tiga kelas dan total mahasiswa adalah 138 orang. Populasinya lebih dari 100 mahasiswa, sehingga peneliti menggunakan teknik random sampling. Peneliti dapat mengambil sampel sekitar $15 \%$ hingga $25 \%$ atau lebih sebagai sampel dan peneliti mengambil setengah dari 100\% adalah 50\%. Jadi, sampel penelitian ini adalah 69 mahasiswa. Peneliti menggunakan metode kuantitatif untuk mendapatkan data yang dibutuhkan. Instrumen penelitian dalam penelitian ini adalah tes dan mengisi formulir kosong. Peneliti menggunakan kalimat tanpa preposisi sebagai instrumen penelitian ini, karena siswa belajar preposisi melalui kalimat. Berdasarkan hasil tes, skor rata-rata preposisi adalah 63,98. Ini dikategorikan tingkat yang baik, yang termasuk dalam interval 61-80. Di mana ada 6 mahasiswa mendapatkan nilai yang sangat baik, 26 mahasiswa mendapatkan skor yang baik, 36 mahasiswa mendapatkan skor yang cukup, 1 mahasiswa mendapatkan nilai yang buruk dan tidak mendapatkan nilai yang sangat buruk. Dengan kesimpulan, mahasiswa Fakultas Hukum 2018/2019 dalam mengidentifikasi preposisi dikategorikan bagus dan mengerti dalam preposisi.
\end{abstract}

Kata Kunci: Kemampuan, preposisi waktu, kalimat

\section{INTRODUCTION}

Learning English is really important. Many countries introduce English to their nation. English has become a major subject in the school's curriculum in Indonesia starting from elementary schools to university level.
Language teaching does not consider language components such as grammatical structure, vocabulary, spelling, and pronunciation. Therefore, grammar needs to be mastered by the students since it is the basic rule of language.

According to Brown (2001) grammar is the system of rules 
governing the conventional arrangement and relationship of words in a sentence. It means that grammar is a description of a language and the way in which units such as words and phrases are combined to produce sentences in the language. From this definition, it seems that grammar plays an important role in combining units of language to form sentences. In grammar, the students are provided with many rules of a language.

One of the important things in grammar aspects is part of speech. In part of speech, there are nouns, pronouns, verbs, adjectives, adverbs, conjunctions, preposition, and interjection. Bakir (2011: 52) said preposition is a word used before a noun to function for describe time, place or position noun or pronoun, etc. While, according to Azhar in Sulastri (2013: 9), the preposition in, at and on are used in time expression.

Preposition is important because they work to connect various parts of a sentence. Even though preposition looks simple, but they have very important functions to English Journal of Indragiri (EJI) change the meaning of the sentences entirely. The correct use of the preposition is very important in English because ungrammatical words or sentences will make some understanding. Most English prepositions have several different functions. At the same time, the different preposition can have very similar uses for example in the morning, on Monday morning, at night and the others. So, it's necessary for students to know more and to master everything about prepositions.

From the explanation above, the researcher conducted the research to know their ability in identifying preposition, especially preposition of time.

\section{METHOD}

The research design was used descriptive research method with a quantitative study as an approach. In this research, the researcher will use a written test (essay) as research instrument especially in filling in the blank form.

2019, Vol. 3, No.1

ISSN. 2549-2144 
According to Steven (1993:

78) Fill in the blank form is a type of question or phrase with one or more words replaced with a blank line, giving the reader the chance to add the missing word. The researcher used a simple sentence without preposition as the instrument of this research, because the students learned preposition through a sentence.

In this research, the population is the first semester of Law Faculty in academic year $2018 / 2019$. It consists of three class and the total of the students are 118 students. In this way, the researcher chooses simple random sampling. Sugiyono (2010: 120) assert about simple random sampling method that takes the samples randomly without caring about the degree of objects of the population. Arikunto (2010: 133) said that the population more than 100 students the researcher can take the sample about $15 \%$ till $25 \%$ or more as the sample and the researcher half of $100 \%$ is $50 \%$. So, the sample of this research is 69 students.

\section{FINDINGS AND DISCUSSION}

In collecting data, the researcher used the written test as a research instrument especially in filling in the blank form. The researcher used a sentence without preposition as the instrument of this research, because the students learned preposition through a sentence.

a. Validity of Instrument

Test validity refers to the degree to which a test measures what is supposed to measure. An instrument is called valid if it can measure what it is hoped to measure (Arikunto, 1997: 160). Various methods can be used to assess the validity of a test; one of them is content validity. Content validity is most frequently used in the evaluation of achievement test with this type of examination. The test will accept if the degree of the difficulty is between $0.30-0.70$, and will be rejected if the degree of difficulty is less than 0.30 (difficult) or bigger than 0.70 (easy). 
To know the validity of the instrument, the researcher uses the formula below:

$$
\mathbf{F v}=\underline{\mathbf{R}}
$$

$\mathbf{N}$

Explanation:

$$
\mathrm{Fv}_{\mathrm{V}}=\text { Validity }
$$

$\mathrm{R}=$ Student's correct answer

$\mathrm{N}=$ Amount of the students

Heaton (2011: 178)

To know the validity of the test, the researcher conducted the tryout.

Table 1. The Result of Validity of the Test

\begin{tabular}{|c|c|c|c|c|c|}
\hline ITEM & $\mathbf{1}$ & $\mathbf{2}$ & $\mathbf{3}$ & $\mathbf{4}$ & $\mathbf{5}$ \\
\hline Correct & 22 & 22 & 16 & 16 & 16 \\
\hline FV & $0.91 \%$ & $0.91 \%$ & $0.67 \%$ & $0.67 \%$ & $0.67 \%$ \\
\hline ITEM & $\mathbf{6}$ & $\mathbf{7}$ & $\mathbf{8}$ & $\mathbf{9}$ & $\mathbf{1 0}$ \\
\hline Correct & 15 & 15 & 16 & 15 & 15 \\
\hline FV & $0.62 \%$ & $0.62 \%$ & $0.67 \%$ & $0.62 \%$ & $0.62 \%$ \\
\hline ITEM & $\mathbf{1 1}$ & $\mathbf{1 2}$ & $\mathbf{1 3}$ & $\mathbf{1 4}$ & $\mathbf{1 5}$ \\
\hline Correct & 7 & 16 & 16 & 16 & 22 \\
\hline FV & $0.29 \%$ & $0.67 \%$ & $0.67 \%$ & $0.67 \%$ & $0.91 \%$ \\
\hline ITEM & $\mathbf{1 6}$ & $\mathbf{1 7}$ & $\mathbf{1 8}$ & $\mathbf{1 9}$ & $\mathbf{2 0}$ \\
\hline Correct & 5 & 7 & 16 & 22 & 7 \\
\hline FV & $0.20 \%$ & $0.29 \%$ & $0.67 \%$ & $0.91 \%$ & $0.29 \%$ \\
\hline ITEM & $\mathbf{2 1}$ & $\mathbf{2 2}$ & $\mathbf{2 3}$ & $\mathbf{2 4}$ & $\mathbf{2 5}$ \\
\hline Correct & 16 & 15 & 15 & 22 & 16 \\
\hline FV & $0.67 \%$ & $0.62 \%$ & $0.62 \%$ & $0.91 \%$ & $0.67 \%$ \\
\hline ITEM & $\mathbf{2 6}$ & $\mathbf{2 7}$ & $\mathbf{2 8}$ & $\mathbf{2 9}$ & $\mathbf{3 0}$ \\
\hline Correct & 15 & 15 & 6 & 16 & 16 \\
\hline FV & $0.62 \%$ & $0.62 \%$ & $0.29 \%$ & $0.67 \%$ & $0.67 \%$ \\
\hline
\end{tabular}

After analyzing the result of validity, the researcher found the result of item difficulties.

It can be concluded that the test was accepted if the degree of the difficulty is between $0.30-0.70$, and English Journal of Indragiri (EJI) was rejected if the degree of difficulty is less than 0.30 (difficult) or bigger than 0.70 (easy). Therefore, the researcher found there were 20 prepositions in a simple sentence in moderate classification.

2019, Vol. 3, No.1 ISSN. 2549-2144 
Then, the classification of the reliability of the test is moderate with value 0.49 . So the researcher took these items like a real test in this research.

b. Reliability of Instrument

The reliability of the instrument is reliable to use is when the test is valid. According to Alias (2005: 235), Reliability is an indication of the consistency between two measures of the same test. The reliability of the test can be measured by using formula. That is:

$$
r_{i i}=\frac{N}{N-1}\left(1-\frac{m(N-m)}{N x^{2}}\right)
$$

$\mathrm{N}$ : Number of items in the test

$\mathrm{m}$ : Mean score on the test for all tests

$x$ : Standard deviation of all the tests' scores

$r_{i i}:$ Reliability

(Heaton, 2010: 164)

Table 2. The Classification of Reliability

\begin{tabular}{|c|c|c|}
\hline No & Reliability & Classification \\
\hline 1 & $0-0.199$ & Very low \\
\hline 2 & $0.20-0.399$ & Low \\
\hline 3 & $0.40-0.599$ & Moderate \\
\hline 4 & $0.60-0.799$ & High \\
\hline 5 & $0.80-1.000$ & Very high \\
\hline
\end{tabular}

(Sugiyono, 2010:257)

The result of the The Classification $r i i=\frac{24}{23}\left(1-\frac{18.92(5.08)}{24(7.56)}\right)$

of the Reliability the test analyzed:

$$
\begin{array}{ll}
r i i=\frac{N}{N-1}\left(1-\frac{m(N-m)}{N x^{2}}\right) & r i i=1,04\left(1-\frac{96.11}{181.44}\right) \\
r i i=\frac{24}{24-1}\left(1-\frac{18.92(24-18.92)}{24(2.75)^{2}}\right) & r i i=1,04(1-0,53) \\
r i i=1,04(0,47)
\end{array}
$$


$r i i=0,49$

Based on the data above, the researcher findings classification of the Reliability of the research on the students' ability in identifying preposition is moderate classification.

c. The result of the Real Test

In the test, the students asked to identify a sentence without preposition form and adding the preposition of time.

The highest score of students' ability in using preposition of time in a simple sentence is 100 with a very good category. Then, the lowest score obtained by students in using preposition of time in a simple sentence is 40 with a poor category. Meanwhile, the mean score of students' ability in identifying preposition is 63.98 with a good category. So, it can conclude that the students' ability in identifying preposition of time in a sentence was a good level. From the scores, the researcher classified the number of students in the level of very good, good, enough, poor, and very poor category.

d. Research Findings

Based on the data presented above, the researcher presented the findings of the research on the students' ability in identifying preposition of time in a sentence.

Table 3. The Classification of Student's Ability in Identifying Preposition of Time in Simple Sentence

\begin{tabular}{|c|c|c|}
\hline No & Qualification & Score \\
\hline 1 & Very Good & 6 \\
\hline 2 & Good & 26 \\
\hline 3 & Enough & 36 \\
\hline 4 & Poor & 1 \\
\hline \multicolumn{2}{|c|}{ Total } & $\mathbf{6 9}$ \\
\hline
\end{tabular}

Based on the result of the test, the researcher has found the English Journal of Indragiri (EJI) mean score of students' ability in identifying preposition of time in a 2019, Vol. 3, No.1 
sentence is 63.98 included in the interval 61-80 which was categorized in good level. Where there are 6 students get a very good score, 26 students get a good score, 36 students get in enough score, 1 student get in a poor score and there is no get in a very poor score. And from that explanation above can indicated a value for personal students especially those for students who are not of excellent class, since the average value of their personal still many are only in good category, but in terms of understanding there are still some students who got good score and enough where the inspection of their personal data found that the difficulty in determining the use of prepositions. From all of the results that have been obtained, it can be deduced that the students' ability in the real of the category of good and understanding to use the preposition.

\section{CONCLUSION}

Based on the result of the test in some indicators, there are many kinds of the preposition of time (On,
In and At) in a sentence that were researched by the researcher at the students of Law Faculty 2018/2019, Islamic University of Indragiri. Therefore, there is some conclusion in this research. The first, the mean score on the students' ability in identifying preposition of time was 63.98 with good level. It means that the students have understood in using preposition of time (At, On and In) because they are able to answer the test with their ability. The second, from that explanation, it can be indicated a value for personal students, since the average value of their personal still many are only in good category, but in terms of understanding there are still some students who got enough where the inspection of their personal data found that the difficulty in determining the use of prepositions. Finally, it means that the students have understood in using preposition of time in a simple sentence because they have learned and able to answer the test with their ability to identify at, on, and in. 


\section{REFERENCES}

Arikunto, Suharsimi. (2006). Prosedur Penelitian Suatu Pendekatan Praktek. Jakarta: PT. Rineka Cipta.

Arikunto, Suharsimi. (2010). Prosedur Penelitian. Jakarta: PT. Rineka Cipta.

Bakir, R. Suyoto. (2011). Focus on English Grammar. Tangerang Selatan.

KARISMA Publishing Group.

Bodgan, Robert \& Steven J. Taylor. (1993). Dasar-Dasar Penelitian Kualitatif. Surabaya: Usaha Nasional.

Creswell, John. W. (2005). Educational Research. Planning, Conducting and Evaluating Quantitative and Qualitative Research (second edition). New Jersey: Pearson Merrill Prentice Hall.

Gay, L. R. and Peter Airasian. (2000). Educational Research. Competencies for Analysis and Application (sixth edition). United States of America: Prentice -Hall, Inc.

Hewings, Martin. (2002). Advanced Grammar in Use. Cambridge: Erlangga
Heaton, J.B. (2010). Writing English Language Test (New Edition). Longman.

Hornby, AS. (2010). Oxford Advanced Learner's Dictionary. Oxford: Oxford University Press.

Margono, S. (1996). Metodologi Penelitian Pendidikan. Semarang : Rineka Cipta.

Richards, Jack C., Platt, John., \& Platt, Heidi. (1992). Longman, Dictionary of Language Teaching \& Applied Linguistics. England: Longman Group UK Limited.

Sudijono, Anas. (2007). Pengantar Statistik Pendidikan. Jakarta: PT. Raja Grafindo Persada.

Sugiyono. (2010). Metode Penelitian Pendidikan (Pendekatan Kuantitatif, Kualitatifm dan $R \& D)$. Bandung: Alfabeta.

Viet, Richard. (1986). Discovering English Grammar. Boston: Houghton Mifflin

Wishon George E, Burks Julia M. (1980). Let's Write English. Canada: Academic Press, Inc. 